\title{
林道切取りのり面における緑化工施工筒所選定法の提案
}

\author{
山本仁志 ${ }^{*}$ - 小林洋司 ${ }^{* *} \cdot$ 遠藤冶郎 $*$ 大塚雍雄 ${ }^{*} \cdot$ 近嵐弘栄*
}

\section{A Trial Plan Regarding the Selection Method of Constructed Points for the Revegetation on the Cutting Slope Surface}

\author{
Yamamoto Masashi*, Kobayashi Hiroshi**, Endo Jiro*, \\ OHtuka Yasuo* and ChIKAARASHI Hiroei*
}

\section{1. はじめに}

林道の切取りのり面における崩落土砂発生面で は, 降雨や降雪の繰り返しで, 崩落土砂量は少量で あるが, 崩落侵食現象が常時発生している。このよ うな崩落侵食土砂の発生が多い切取りのり面には, 緑化工を施工して崩落侵食の対策とすることが必要 である。そのために，緑化工を施工するに当たり， 崩落侵食土砂量の推定値に基づいて緑化工の施工箇 所や工種, 混播割合を評価判定するのが望ましい。

一般道路, 鉄道における直接交通障害となる切取 りのり面の崩壊については, 降雨との関係，崩壊発 生予測やのり面崩壊の危険度評価などの研究があ $ろ^{2,5,59}$ 。林道では, 谷沿いから山腹に施工されるにし たがい, 岩石のり面よりも土砂, 土石の切取りのり 面が多くなり,このような林道の切取りのり面では, 降雪, 降雨の繰り返しで, 崩落侵食土砂が常時発生 している。この崩落土砂は, 林道保全の上からも少 なからぬ影響がある ${ }^{1,3,4)}$

新設林道では切取りのり面の全面に緑化工を行う ようになったが，既設林道では裸地状態の切取りの り面が少なからず見られる。低規格林道や簡易林道 においてはほとんどの切取りのり面に緑化工が行わ れていない。

* 新潟大学農学部

Fac. of Agric., Niigata Univ. Niigata, Igarashi 950-21

** 東京大学農学部

Fac. of Agric., Univ. of Tokyo Tokyo, Bunkyo-ku 113
このような崩落土砂侵食の発生の多い切取りのり 面には緑化工を施工することが必要である。そのた めに, 崩落侵食土砂量で路線を区分し, 緑化工の施 工箇所の適正な選定，コンクリートよう壁か，金網 張り工かの施工種の判別, また, 種子資材の混播割 合を評価するために，数量化法が応用されてい る ${ }^{6,7,8)}$ 。ここでは, のり面形状観察の要因と土質工学 的要因から，のり面崩落侵食土砂量区分を予測判定 し, のり面崩落侵食土砂量の推定を試みた。

まず，数量化 I 類を適用し，説明要因としては， のり面凹凸形状観察から得た要因に加えて, 容易に 行える土質工学試験の要因で, 崩落侵食土砂量の推 定を試みた。

次に数量化II類を適用し，のり面崩壊侵食土砂量 区分を外的基準にして解析した。

\section{2. 実験方法および資料}

資料は，花崗岩を母岩とする粘性土質の降雨の多 い山岳地域である新潟県五頭山国有林林道切取りの り面から得られた。1987年から1988年にかけて, 前 橋営林局新発田営林署管内の五頭山塊西斜面の林道 6 路線 (総延長約 $10 \mathrm{~km}$ ) の切取りのり面裸地部分か ら得た46箇所の直接一面セン断試験, のり面表土の フルイ分け試験, 実容積試験の土質工学的要因との り面形状調查の環境要因について調査デー夕を得 た。

崩落侵食土砂量を予測するために, 説明要因とし て数量で表現出来る定量的要因だけでなく, 分類で 
表現できる定性的要因(例えば，のり面の位置が凹， 凸地形である。または平行地形である。という表現 ができる）を含むため，今回は数量化 I 類，II類の 手法を適用して土質工学的要因, 環境要因と崩落侵 食土砂量の推定量に関係する要因を検討した ${ }^{10)}$ 。ま た,この手法を適用することによって定量的計測值 を何 $\mathrm{m}$ 以下，何 $\mathrm{m}$ から何 $\mathrm{m}$ までというように分類 し, 大小関係での比較表現が可能である。

崩落侵食土砂量の算出モデルとして, 次のような 体積を理論值とした。のり面形状の測定は図-1 1 示 す $\mathrm{A}$ 点から $\mathrm{B}$ 点に測線を張り, この測線 $\mathrm{AB}$ と地表 線との鉛直距離を測線長 (測線 $\mathrm{AB}$ 間) 斜距 $50 \mathrm{~cm}$ 間 隔で下から測定した。さらに測線 $\mathrm{AB}$ の長さ（L) と, 測線 $\mathrm{AB}$ と路盤線ののり面側の角 $(\alpha)(\angle \mathrm{ABC})$ を測定した。のり面崩壊土砂量はのり面 $1 \mathrm{~m}^{2}$ 当りに 侵食されたであろう推定土砂量である。この算出方 法は図-1 亿示すように道路横断図にのり面形状を 書き込み，のり面施工勾配線と地表線とで囲まれた 山側の部分 (図- 1 で右側, ハッチング部分) の面積 に幅 $1 \mathrm{~m}$ を乗じ施工のり長, 施工経過年で除した值 である ${ }^{11,12,14) 。}$

直線一面セン断試験は在来型セン断試験機を用い て行った。この試験の試料はマイター・ボックス(直 径 $60 \mathrm{~mm}$ ) と突き棒（直径 $25 \mathrm{~mm}$ 突き固め圧力 10 Kgf）とで15回突き固めた。試験はセン断速度 $1 \mathrm{~mm} /$ $\min$ で, 垂直荷重を $0.05 ， 0.15 ， 0.25 \mathrm{Kgf}$ と変化さ せて行った。その結果, 1 試料につき 3 個のデー夕 を得た。さらにのり面表土のサンプルを用い 4.76

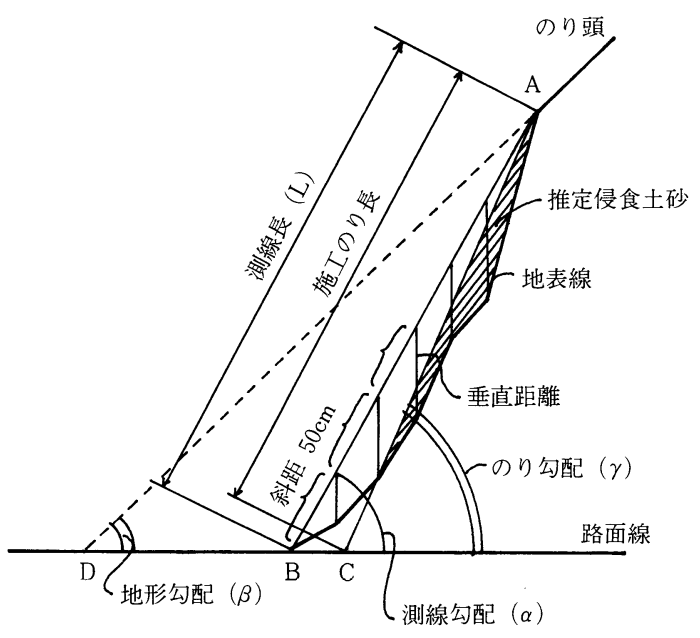

図 1 測線によるのり面測量 $\mathrm{mm} \sim 0.74 \mathrm{~mm}$ の標準フルイを用いてフルイ分け試 験を行った ${ }^{13)}$ 。

のり面表土から採取した土壌サンプルは重量を測 定した後, DIK-100 型実容積試験機を用いて測定 し, 固相重量, 孔隙率, 仮比重, 含水量を算出し た ${ }^{15,16)}$ 。

のり面形状の調査をした五頭山塊の地質は, 主に 花崗岩であり，他に第三紀層，第四紀層が分布する。 降雨量は, 近傍の津川観測点で年降雨量 $2,549 \mathrm{~mm}$ であった

\section{3. 算出結果と考察}

\section{1 崩落侵食土砂量に影響する要因の抽出}

崩壊には，素因として，地質，土質，地形，斜面 勾配などがあげられ, 誘因として, 降雨, 融雪の作 用や人為的作用などがある。また，林道切取りのり 面崩落の場合, 地形, 地質, 斜面勾配, 標高, のり 面勾配, 降雨, 融雪, 湧水, のり肩の林況などが考 えられる。そこで，とりあげた要因は，土質工学的 要因として, 見かけの内部摩擦角 $(\phi)$, 見かけの粘 着力 (c), 標準フルイ $2,000 \mu \mathrm{m}$ 通過率, $420 \mu \mathrm{m}$ 通 過率, $74 \mu \mathrm{m}$ 通過率, $100 \mathrm{ml}$ の実容積, 重量, 固相 重量, 孔吵率, 見かけの比重, 含水量の 11 項目と, のり面形状調查から得た環境要因として,1）のり面 方位，2）地形勾配，3）切込み量(切取り深さ)，4） 施工のり面勾配，5）施工のり長，6）標高，7）のり 面位置(地形図での凹地形, 平行地形, 凸地形)，8) のり面形状型（のり面が全面で侵食され，堆積土が ほとんどない型：A型，のり面上部が侵食され，中 央部から下部に堆積した型：B型, のり面中央部よ り上部が侵食され，下部に堆積がない型：C型，の り面中央部より下部まで侵食され，堆積がない型： $\mathrm{D}$ 型，判定できない型： $\mathrm{E}$ 型）の 8 項目である。

3.2 数量化手法の適用の結果

3.2.1 数量化 I 類(外的基準を崩落侵食土砂量と した場合）

まず，説明要因について述べると，崩落侵食土砂 量との単相関の相関係数を求めた場合, 各々の要因 には強い相関は見られなかった。土質工学的要因で は, 直接一面セン断試験の見かけの粘着力が見かけ の内部摩擦角より高く, 標準フルイ試験の $2,000 \mu \mathrm{m}$ 標準フルイ試験が $420 \mu \mathrm{m}, 74 \mu \mathrm{m}$ 標準フルイ試験よ り高く, 実容積試験の重量, 固相重量が他の試験項 目より高かった。7つの環境要因では，のり勾配， 
表 1 環境要因 8 アイテム31カテゴリーと土質工学的要因11アイテム31カテゴリーの表（試算過程におけるアイテム・ カテゴリーに対する重相関係数の変化)

\begin{tabular}{|c|c|c|c|c|c|c|c|c|}
\hline アイテム & カテゴリー & 試算 1 & 試算 2 & 試算 3 & 試算 4 & 試算 5 & 試算 6 & 試算 7 \\
\hline 見かけの内部角 & $\widetilde{3}_{35^{\circ}}^{34^{\circ}}$ & $\stackrel{2}{0} 102^{*}$ & & $\stackrel{2}{0.484^{*}}$ & & & & \\
\hline 見かけの粘着力 & $\begin{array}{c}\sim 0.2 \mathrm{kgf} / \mathrm{m}^{2} \\
0.2 \sim 0.3 \mathrm{kgf} / \mathrm{m}^{2} \\
0.3 \mathrm{kgf} / \mathrm{m}^{2} \sim\end{array}$ & $\begin{array}{c}3 \\
0.901^{*}\end{array}$ & & $\begin{array}{c}3 \\
0.476^{*}\end{array}$ & & & $0.2^{35} 5^{*}$ & \\
\hline $\begin{array}{l}2,000 \mu \mathrm{m} \text { フルイ } \\
\text { 通過率 }\end{array}$ & $\begin{array}{l}\sim 60 \% \\
60 \sim 70 \% \\
70 \%\end{array}$ & 0. $\stackrel{3}{965^{*}}$ & & & $\stackrel{3}{0.665^{*}}$ & & & \\
\hline $\begin{array}{l}420 \mu \mathrm{m} \\
\text { 通過率 }\end{array}$ & $\begin{array}{l}\sim 10 \% \\
10 \sim 20 \% \\
20 \% \sim\end{array}$ & $\stackrel{3}{0.969 *}$ & & & $\stackrel{3}{0.769^{*}}$ & & & \\
\hline 率 $\mu \mathrm{m}$ フルイ通過 & $\begin{array}{c}2 \widetilde{2.0 \%} \\
2.0 \sim 4.0 \%\end{array}$ & $\stackrel{2}{2}{ }^{*} 4^{*}$ & & & $\begin{array}{c}2 \\
0.560^{*}\end{array}$ & & & \\
\hline 実容積 & $\begin{array}{l}30 \sim 45 \mathrm{ml} \\
46 \sim 60 \mathrm{ml} \\
61 \sim 75 \mathrm{ml}\end{array}$ & $\stackrel{3}{0}{ }^{*} 5^{*}$ & & & & $\begin{array}{c}3 \\
0.383^{*}\end{array}$ & & $\begin{array}{c}3 \\
0.534^{*}\end{array}$ \\
\hline 重量 & $\widetilde{130 \mathrm{~g}}$ & $\stackrel{2}{0.060^{*}}$ & & & & $\stackrel{2}{2} 0.657^{*}$ & & \\
\hline 固相重量 & $\begin{array}{l}\sim 70 \mathrm{~g} \\
70 \sim 100 \mathrm{~g} \\
100 \mathrm{~g} \sim\end{array}$ & $\stackrel{3}{0.932^{*}}$ & & & & $\stackrel{3}{0.512^{*}}$ & & \\
\hline 孔隙率 & 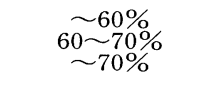 & $0 . \stackrel{3}{955^{*}}$ & & & & $0 . \stackrel{3}{210^{*}}$ & & \\
\hline 比重 & $\begin{array}{l}\sim 2.50 \\
\sim 2.60 \\
\sim 2.70 \\
2.70 \sim\end{array}$ & $\stackrel{4}{0.935^{*}}$ & & & & $\stackrel{4}{0.560^{*}}$ & & $\stackrel{4}{0.370^{*}}$ \\
\hline 含水量 & $\begin{array}{c}\sim 20 \% \\
20 \sim 30 \% \\
30 \% \sim\end{array}$ & $\stackrel{3}{9}{ }^{*}$ & & & & $\stackrel{3}{0.224^{*}}$ & & \\
\hline のり面方位 & $\begin{array}{c}\mathrm{N} \\
\mathrm{S} \\
\mathrm{E} \\
\mathrm{W} \\
\mathrm{NE} \\
\mathrm{NW} \\
\mathrm{SE} \\
\mathrm{SW}\end{array}$ & $\stackrel{8}{0}$ & $\stackrel{8}{0.485^{*}}$ & $\stackrel{8}{0.567^{*}}$ & $\stackrel{8}{0.714^{*}}$ & $\stackrel{8}{0.706^{*}}$ & $\stackrel{8}{0.515^{*}}$ & $\stackrel{8}{0.594^{*}}$ \\
\hline 切込み量 & $\underset{4 \mathrm{~m} \sim}{\sim 3 \mathrm{~m}}$ & $\stackrel{3}{961^{*}}$ & $\stackrel{3}{0.194^{*}}$ & $0.351^{*}$ & $\stackrel{3}{0.572^{*}}$ & $0.3^{3} 10^{*}$ & & \\
\hline 地形勾配 & $\begin{array}{l}\sim 22^{\circ} \\
\sim 31^{\circ} \\
32^{\circ} \sim \\
\sim 20^{\circ} \\
\sim 30^{\circ} \\
\sim 35^{\circ} \\
\sim 40^{\circ} \\
40^{\circ} \sim\end{array}$ & $\stackrel{3}{0.963^{*}}$ & $\stackrel{3}{0.049^{*}}$ & $\begin{array}{c}3 \\
0.278^{*}\end{array}$ & $\begin{array}{c}3 \\
0.473^{*}\end{array}$ & $0.350^{*}$ & $\begin{array}{c}5 \\
0.485^{*}\end{array}$ & \\
\hline のり長 & $\begin{array}{l}\underset{3 \mathrm{~m} \sim 4 \mathrm{~m}}{\sim} \underset{\mathrm{m}}{4 \mathrm{~m} \sim} \mathrm{m} \\
4 \mathrm{~m}\end{array}$ & $\frac{4}{0.847^{*}}$ & $\frac{4}{0.100^{*}}$ & $\frac{4}{0.353^{*}}$ & $\begin{array}{c}4 \\
0.291^{*}\end{array}$ & $\begin{array}{c}4 \\
0.463^{*}\end{array}$ & & \\
\hline のり面勾配 & $\begin{array}{l}\sim 55^{\circ} \\
66^{\circ} \sim 60^{\circ}\end{array}$ & $\begin{array}{c}3 \\
0.737^{*}\end{array}$ & $\stackrel{3}{0.24}$ * & $\frac{3}{0.338^{*}}$ & $\begin{array}{c}3 \\
0.429^{*}\end{array}$ & $\frac{3}{0.545^{*}}$ & $\frac{3}{0.415^{*}}$ & \\
\hline 標高 & 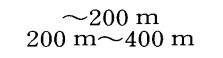 & $\stackrel{2}{2} 0.813^{*}$ & $\stackrel{2}{2} 252^{*}$ & $\stackrel{2}{2}{ }^{*}$ & $\stackrel{2}{2}{ }^{*}{ }^{*}$ & $\stackrel{2}{2}$ 0. $407^{*}$ & & \\
\hline のり面位置 & $\begin{array}{l}\text { 谷 } \\
\text { 荱椱 }\end{array}$ & $\frac{3}{0.823^{*}}$ & $\frac{3}{0.341^{*}}$ & $0.3^{236^{*}}$ & $0 . \stackrel{3}{0.57^{*}}$ & $\stackrel{3}{0.321^{*}}$ & & $\stackrel{3}{0.431^{*}}$ \\
\hline 形状 & $\begin{array}{l}\mathrm{A} \text { 型 } \\
\mathrm{B} \text { 型 } \\
\mathrm{C} \text { 型 } \\
\mathrm{D} \text { 型 } \\
\mathrm{E} \text { 型 }\end{array}$ & $\frac{5}{94} 4^{*}$ & & $\stackrel{5}{6}{ }^{67} 6^{*}$ & $\stackrel{5}{0.719^{*}}$ & $\stackrel{5}{0.754^{*}}$ & & \\
\hline アイテム数 & & 19 & 7 & 10 & 11 & 14 & 4 & 4 \\
\hline カテゴリー数 & & 62 & 26 & 36 & 39 & 49 & 19 & 18 \\
\hline 重相関係数 & & 0.985 & 0.631 & 0.810 & 0.896 & 0.882 & 0.666 & 0.710 \\
\hline
\end{tabular}

表中, 上の数字はカテゴリー数 *は偏相関係数 
のり長, のり面位置が地形勾配, のり面方位, 切込 量, 標高に比べて高い值を示した。しかし，全体的 には，相関係数は，0.29〜0.04の間で個々の要因と 崩落侵食土砂量との間に相関があるとは言えない。 そこで, 崩落侵食土砂量は, 一個の説明要因でなく, 寄与率の高い適切な説明要因数個を用いて決定する のが妥当であると考元られる。崩落侵食土砂量を多 くの要因について調查, 分析を行うには多大の労力 と経費がかかるので, 説明要因（調査項目）をしぼ り込むことが求められている。崩落侵食土砂量は, 数個の説明要因で説明が可能であり, 調査にかかる 労力と経費が節減できる。

土質工学的要因11項目と環境要因 8 項目を用いて 各アイテムの各カテゴリーのカテゴリー数量 (SCORE) を算出するために, 各アイテムのカテゴ リーを表-1のように表現した。切取りのり面におい て各アイテムの該当するカテゴリーのカテゴリー数 量を総計した值が, その切取りのり面の予測崩落侵 食土砂量である。

まず，土質工学的要因11アイテムと環境要因 8 ア イテムの18アイテム 62 カゴリーで算出した場合, 表- 1 の試算 1 のように重相関係数が 0.985 となり, 重相関係数は高いが, 説明要因の数が多いため, 以 下のように試算を繰り返した。次に, 環境要因のの り面形状は, のり面が崩落を生じ, 侵食された後の 形, すなわち侵食後ののり面表土の状態と考えられ るので, これを除き, 環境要因は, のり面方位, 切 込量, 地形勾配, のり勾配, のり長, 標高, のり面 位置の 7 項目とした。環境要因 7 アイテムの試算(表 -1 の試算 2 )による重相関係数は，0.631と低いが, 環境要因 7 項目による崩壊土砂量の算定も可能と考 えられる。ここで, 土質工学的要因すべてを各切取 りのり面で測定することは経済的, 人的負担が大き いと思われる。しかし, 土質工学要因はのり面の基 本的性質を表しているので, 完全に除外しない場合 の例を考える。7 環境要因は, 観測が簡易な上, 短 期間に調查が行えるものと考えられる。そこで, 直
接一面セン断試験と環境要因との組合せ, 標準フル イ分け試験と環境要因との組合せ, 実容積試験と環 境要因との組合わせを考えた。この 3 組合わせで試 算 (表- 1 の試算 $3 ， 4 ， 5$ ) の結果, これらの重相 関係数は， $0.810 ， 0.896$ と0.882であった。

次に, 土質工学的要因と環境要因の相関係数の小 さいアイテム, また偏相関係数の低いアイテムを順 次除いて, 数量化 I 類を用いてアイテム・カテゴリー の数量の算出を順次アイテムを減らしながら, 試算 を繰り返した。すなわち, のり面形状は先の理由か ら除き,また, 偏相関係数の小さな「標高」を除い て試算を繰り返し行った。その結果, 直接一面セン 断試験に関しては見かけの粘着力, 環境要因ではの り面方位, 地形勾配, 施工のり面勾配が残り, その 重相関係数は0.666であった(表- 1 の試算 6 )。また, 実容積試験の 6 アイテムと環境要因 7 アイテムの組

表 3 4 アイカム・19カテゴリーカテゴリーの数量 (SCORE)

\begin{tabular}{ccc}
\hline アイテム & カテゴリー & 数量 (score) \\
\hline $420 \mu \mathrm{m}$ 標準フルイ & $\sim 10 \%$ & 0.153 \\
通過率 & $\sim 20 \%$ & 0.120 \\
& $20 \% \sim$ & 0.012 \\
\hline のり面方位 & $\mathrm{N}$ & 0.000 \\
& $\mathrm{NE}$ & 0.096 \\
& $\mathrm{E}$ & 0.016 \\
& $\mathrm{SE}$ & 0.022 \\
& $\mathrm{~S}$ & -0.068 \\
& $\mathrm{SW}$ & -0.092 \\
& $\mathrm{~W}$ & -0.188 \\
& $\mathrm{NW}$ & 0.103 \\
\hline 地形勾配 & $\sim 20^{\circ}$ & 0.000 \\
& $\sim 30^{\circ}$ & 0.035 \\
& $\sim 35^{\circ}$ & 0.028 \\
& $\sim 40^{\circ}$ & 0.155 \\
& $40^{\circ} \sim$ & 0.011 \\
\hline のり勾配 & $\sim 55^{\circ}$ & 0.000 \\
& $56 \sim 60^{\circ}$ & -0.093 \\
& $61^{\circ} \sim$ & -0.091 \\
\hline
\end{tabular}

表 2 相関表

\begin{tabular}{cccrc}
\hline & $420 \mu \mathrm{m}$ 標準フルイ通過率 & のり面方位 & 地形勾配 & のり勾配 \\
\hline $420 \mu \mathrm{m}$ 標準フルイ通過率 & 1.000 & 0.299 & 0.008 & -0.297 \\
のり面方位 & & 1.000 & -0.294 & -0.133 \\
地形勾配 & & & 1.000 & -0.034 \\
のり勾配 & & & & 1.000 \\
\hline
\end{tabular}


山本・小林・遠藤・大塚・近嵐：林道切取りのり面における緑化工施工箇所選定法の提案

表 5 のり面崩落侵食量の表 3 による計算例

\begin{tabular}{ccccccc}
\hline & $\begin{array}{c}\mathrm{m}^{2} \text { 当たりの } \\
\text { 侵食 }\left(\mathrm{m}^{3}\right)\end{array}$ & $\begin{array}{c}420 \mu \mathrm{m} \text { フルイ } \\
\text { 通過率 }(\%)\end{array}$ & 方位 & $\begin{array}{c}\text { 地形勾配 } \\
\left({ }^{\circ}\right)\end{array}$ & $\begin{array}{c}\text { のり勾配 } \\
\left({ }^{\circ}\right)\end{array}$ & $\begin{array}{c}\text { 推定崩落 } \\
\text { 侵食量 }\left(\mathrm{m}^{2}\right)\end{array}$ \\
\hline 角田 & 0.0234 & 32.8 & $\mathrm{SE}$ & 19 & 55 & \\
スコアー* & & 0.012 & 0.022 & 0.000 & 0.000 & 0.034 \\
弥彦 $\mathrm{A}$ & 0.0479 & 38.6 & $\mathrm{NW}$ & 23 & 63 & \\
スコアー* & & 0.012 & 0.103 & 0.035 & -0.091 & 0.059 \\
弥彦B & 0.0318 & 34.0 & $\mathrm{NW}$ & 18 & 63 & \\
スコアー* & & 0.012 & 0.103 & 0.000 & -0.091 & 0.024 \\
\hline
\end{tabular}

*:表 3 参照

表 4 重相関係数と偏相関係数

\begin{tabular}{ccc}
\hline 偏相関係数 & $420 \mu \mathrm{m}$ 標準フルイ通過率 & 0.569 \\
& のり面方位 & 0.675 \\
& 地形勾配 & 0.621 \\
& のり勾配 & 0.536 \\
\hline 重相関係数 & & 0.769 \\
\hline
\end{tabular}

合せでの試算では，実容積，比重，のり面方位，の り面位置の 4 要因となった。この重相関係数は 0.710 であった（表-1の試算 7 )。

さらに標準フルイ試験の 3 アイテムと環境要因 7 アイテム(のり面形状を除く)の組合せでは $420 \mu \mathrm{m}$ 標準フルイ通過率と 3 環境要因（のり面方位, 地形 勾配，のり面勾配)が残り，重相関係数は 0.769 とな ったのでこれを経済的な説明要因と位置づけた。こ の結果の相関表を表- 2 に,カテゴリー数量 (SCORE) を表- 3 に，そして重相関係数と偏相関係 数を表- 4 に示した。

結果の表- 3 の具体的なデー夕による推定量の計 算例を表- 5 に示した。適用地点は, 地量化 I 類によ るスコア算出点と異なる弥彦, 角田山の 3 箇所であ る。適用地点ののり面測定值を表- 3 の該当するカテ ゴリーの数値に置き換えると, その合計值は推定崩 落侵食量となる。すなわち, 一番目の角田の場合, $420 \mu \mathrm{m}$ 標準フルイ通過率が $32.8 \%$ で0.012, のり面 方位が SE で 0.022 ，地形勾配が $19^{\circ}$ で $0.000 ，$ のり面 勾配が $55^{\circ}$ で 0.000 となり，その合計は，0.034であ る。この 0.034 がこの測定のり面箇所における $1 \mathrm{~m}^{2}$ 当たり $0.034 \mathrm{~m}^{3}$ の崩落侵食土砂量という推定值で ある。

\subsection{2 数量化II類 (外的基準をのり面崩壊土砂量} 区分（多い，少ないの 2 分類）にした場合） のり面が侵食され, 具体的にのり面の土砂の移動 が進行している間は植生は入らない。このため, 土
砂の移動を防止する緑化基礎工の施工を付加したの り面保護工が必要となる。ここで，のり面崩落侵食 土砂量を $1 \mathrm{~m}^{2}$ 当たり $0.02 \mathrm{~m}^{3}$ 以下とそれ以上との 2 分類を外的基準にして数量化II類の手法で， 5 つ の環境要因（のり面方位, 地形勾配, 切込量, のり 勾配，標高）と測定容易な土質工学的要因の $420 \mu \mathrm{m}$ 標準フルイ通過率, 土の自然含水比を用いて検討し た。

その結果, 表- 6 のような SCORE と偏相関係数, 重相関係数，大小の区分点 -0.4616 を得た。のり面 崩落侵食土砂量が $1 \mathrm{~m}^{2}$ 当たり $0.02 \mathrm{~m}^{3}$ 以下の場合 の具体的なカテゴリーの組合せは, のり面方位がW と NW と SE で, 地形勾配が $35^{\circ}$ 以下で, 切込量が 2 $\mathrm{m}$ から $3 \mathrm{~m}$ と $4 \mathrm{~m}$ から $6 \mathrm{~m}$ で, のり勾配が $60^{\circ}$ 以下 で, 標高が $200 \mathrm{~m}$ 以上で, $420 \mu \mathrm{m}$ 標準フルイ通過率 が10\%以下と $20 \%$ 以上で, 含水比が $20 \%$ 以上である。 対象崩落侵食のり面において，7アイテムの該当カ テゴリーが上記のカテゴリーの組合わせの場合, SCOREの合計值が最大值で-1.431, 最小值で -5.204 となり, 崩落侵食土砂量の多少を判別する区 分点－0.4616より小さい。これは「のり面崩落侵食 土砂量が $1 \mathrm{~m}^{2}$ 当たり $0.02 \mathrm{~m}^{3}$ 以下」と判定できる。

例えば崩落侵食土砂量の多い例として, 角田山の のり面の 2 測定箇所を表- 7 に示す。表- 7 のように 各アイテム・カテゴリーに該当した表- 5 の数值の合 計值は, 角田 $\mathrm{A}$ と Bののり面箇所でー0.016, -0.085 となり, 区分点值より大きく, 崩落侵食土砂量 $\left(\mathrm{m}^{2}\right.$ 当たりの侵食量）は， $0.045 ， 0.044$ である。すなわ ち崩落侵食土砂量が $1 \mathrm{~m}^{2}$ 当たり $0.02 \mathrm{~m}^{3}$ より多い と判定できる。

したがって, 緑化工を行う場合崩落侵食土砂量の 移動を防ぐための緑化基礎工の工事が必要と考えら れる。

このように環境要因と $420 \mu \mathrm{m}$ 標準フルイ通過 
表 6 環境要因と土質工学的要因の数量表

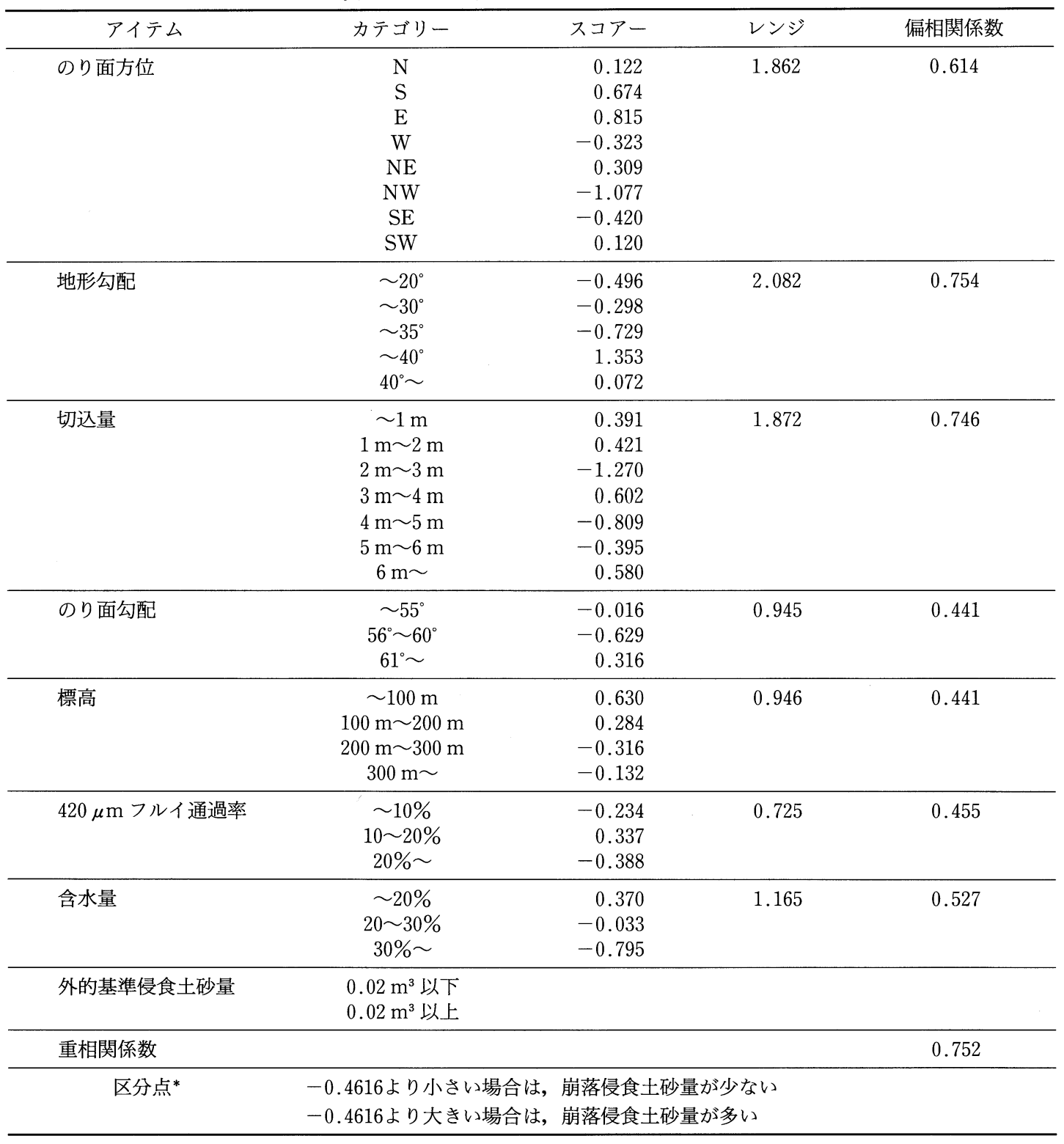

*：(区分点は，対象のり面における7アイテムの該当スコアの合計值による 2 分類を判定する区分值（しきい值）

表 7 のり面崩落侵食土砂量区分点による判別計算例

\begin{tabular}{|c|c|c|c|c|c|c|c|c|c|}
\hline & $\begin{array}{c}\mathrm{m}^{2} \text { 当たり } \\
\text { 侵食量 } \\
\left(\mathrm{m}^{3}\right)\end{array}$ & 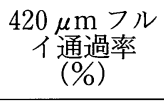 & $\begin{array}{c}\text { 含水率 } \\
(\%)\end{array}$ & 方位 & $\begin{array}{c}\text { 地形勾配 } \\
\left({ }^{\circ}\right)\end{array}$ & $\begin{array}{c}\text { 切込量 } \\
\text { (m) }\end{array}$ & $\begin{array}{c}\text { のり勾配 } \\
\left({ }^{\circ}\right)\end{array}$ & $\begin{array}{l}\text { 標高 } \\
(\mathrm{m})\end{array}$ & 判定得点 \\
\hline 角田 A & 0.045 & 39.5 & 42.8 & $\mathrm{E}$ & 14 & 11.22 & 48 & 120 & \\
\hline スコアー* & & -0.388 & -0.795 & 0.815 & -0.496 & 0.580 & -0.016 & 0.284 & -0.016 \\
\hline 角田 B & 0.044 & 41.9 & 37.5 & $\mathrm{E}$ & 18 & 6.52 & 59 & 85 & \\
\hline スコアー* & & -0.388 & -0.795 & 0.815 & -0.298 & 0.580 & -0.629 & 0.630 & -0.085 \\
\hline
\end{tabular}

*：表 6参照 
率，土の自然含水比を調べることにより緑化計画の 段階において，施工か否か，また施工種，混播など の見通しをつけることができると考えられる。すな わち裸地のままで良いか, 将来のり面が崩落を生じ, のり面崩壊の素因となり得る可能性があるか否かも 設計段階で見通しが得られるものと思う。

\section{4. 結論}

崩壊侵食土砂量は, 土質工学的要因の $420 \mu \mathrm{m}$ 標 準フルイ通過率と 3 環境要因すなわちのり面方位, 地形勾配，施工のり面勾配で推定できた。次に数量 化 III類を適用し，のり面崩壊侵食土砂量区分を外的 基準にして解析した結果，5つの環境因子（のり面 方位, 地形勾配, 切込量, のり面勾配，標高）と土 質工学的要因の $420 \mu \mathrm{m}$ 標準フルイ通過率, 土の自 然含水比から崩壊土砂量の大小を区分することがで きた。この結果を総合してのり面凹凸形状観察要因 と測定容易な土質工学的要因から, のり面崩落侵食 土砂量区分で, 緑化工施工箅所を選定し, のり面崩 落侵食土砂量の推定量に応じた緑化工の設計の選択 評価に応用できると考えられる。

この方法による調查資料をもとに，のり面形状の 環境要因と容易に測定できる土質工学的要因で崩落 侵食土砂量を推定評価し, 緑化施工箇所や緑化施工 箇所における緑化工種の選定および組合せ，播種の 組合せおよび混合割合を設計することが可能と思わ れる。

したがって，ここに提案する方法は，花崗岩を母 岩とする粘性土質で降雨の多い山岳地域において有 効な工種の選定, 設計施工の順位などを検討する資 料として有用であると推測できる。

\section{参考文献}

1）井上源基・福田章史・市原恒一・福田光正：林道法
面工法の評価検討, 昭和56年度国有林野事業会計技 術開発試験成績報告書, 林業試験場, 137-171, 1981

2）神村 孝・村木由尚：ファジイエキスパートシステ ムによる表層崩壊危険度診断, 平成元年砂防学会発 表会概要集, 153-154，1989

3）菊池政泰：林道の法面崩壊に関する研究(2), 第 9 回 林道研究発表論文集, 89-93, 1974

4）菊池政泰 : 林道の切取法面の安定度解析, 85回日林 講, $318-320,1980$

5）小林秀孝・福本 泉・谷岡秀幸・斉藤辰男：切取・ 斜面の崩壊危険度評価について, 土木学会第45回年 次学術講演会概要集 $3,882-883,1990$

6）久保田圭助・武井昌博：数量化法による切取のり面 の安全度解析, 土木学会論文報告集194, 141-150, 1971

7）持永竜一郎・福山俊郎：シラスのり面崩壊に関する 要因分析, 土木学会論文報告集197, 101-110, 1972

8）南部光弘・軽部大蔵・浅野雅行：統計的手法による 道路用盛土のり面の安定度解析, 土木学会論文報告 集241，93-103，1975

9）打萩珠男：ひと雨による山腹崩壊土量の実用計算 法試案, 新砂防69, 30-35, 1968

10）山本宏夫・福山俊郎：数量化理論による切取りのり 面の崩壊についての研究, 第27回土木学会学術講演 会講演概要集第IV部会, 269-272, 1972

11）山本仁志・矢部茂明：林道の切取りのり面の崩落土 砂量について，36日目林関東支論，223-224，1985

12) 山本仁志：五頭山塊の林道のり面崩落土砂量につ いて，38回日林関東支論，267-268，1986

13）山本仁志・佐々木克実：新潟県下の林道切取りのり 面崩落土についての一考察, 39回日林関東支論, 273 $-274,1987$

14）山本仁志：佐渡演習林大倉林道のり面の崩落土に ついて，新潟大演報 $20,173-186,1987$

15）山本仁志・為永二郎：五頭山塊の切取りのり面崩落 土砂量についての一考察, 40回日林関東支論, 229230, 1988

16）山本仁志：林道切取りのり面崩落土砂量の推定, 日 林誌74(1)，37-43，1992

(1995.12.25受理) 